\title{
Evaluation of sugarcane laboratory ensiling and analysis techniques
}

\author{
André de Faria Pedroso ${ }^{1}$, Alexandre Mendonça Pedroso ${ }^{1}$, Waldomiro Barioni Júnior ${ }^{1}$, \\ Gilberto Batista de Souza ${ }^{1}$
}

\author{
${ }^{1}$ Embrapa Pecuária Sudeste, São Carlos, SP, Brasil.
}

\begin{abstract}
The objective was to evaluate the effects of laboratory-silo type and method of silage extract production, respectively, on sugarcane silage fermentation and recovery of fermentation products. Sugarcane was mechanically harvested and ensiled in three different types of laboratory silos (five replicates): $9.7 \times 30 \mathrm{~cm}$ PVC tubes with tight lids, equipped or unequipped with Bunsen valves, and $20 \mathrm{~L}$ plastic buckets with tight lids and Bunsen valves. Three methods were used to produce silage extracts for $\mathrm{pH}$, ethanol, acetic and lactic acids determination: extraction of silage juice by a hydraulic press and production of water extracts using a stomacher or a blender. Total dry matter loss $(231 \mathrm{~g} / \mathrm{kg} \mathrm{DM})$ was not affected by silo type. No interactions between silo type and method of silage extract production were observed for ethanol and organic acids contents in the silages. Interaction between silo type and method of silage extract preparation was detected for $\mathrm{pH}$. Silo type affected ethanol content but did not affect lactic and acetic acids concentration in the silages. Dry matter, crude protein, neutral detergent fiber and ash were not affected by silo type. The method used to produce silage extracts affected the recovery of all fermentation products analyzed in the silages. Recovery of ethanol and acetic acid was higher when silage extracts were produced using a blender. For lactic acid recovery, the hydraulic press method was superior to the other two methods. Silage fermentation pattern is not affected by silo type, but the method used to produce silage extracts and some characteristics of silos affect the recovery of volatile fermentation products.
\end{abstract}

Key Words: acetic acid, ethanol, laboratory silo, lactic acid, silage extract, sugarcane silage

\section{Introduction}

Fermentation in sugarcane silages is dominated by yeasts, resulting in high ethanol content in the forage (Alli et al., 1982). The ethanol content has a direct relationship with dry matter (DM) losses and an inverse relationship with nutritional value of these silages (Pedroso et al., 2005) making it essential to use additives to control alcoholic fermentation during ensilage. Usually, aspects of silage fermentation and additives are evaluated in laboratory silos but types of silos vary considerably, as do the methods used to produce silage extracts for analysis of fermentation products.

The usefulness of laboratory silos in forage conservation research has been long established (Wilson and Wilkins, 1972), but studies on the effects of differences in laboratory silos on silage fermentation are scarce (O'Kiely and Wilson, 1991 in Cherney et al., 2004; Rodrigues et al., 2002; Cherney et al., 2004). Analysis of fermentation products is normally carried out in water extracts produced in a blender

Received December 19, 2012 and accepted November 27, 2013.

Corresponding author: andre.pedroso@embrapa.br

http://dx.doi.org/10.1590/S1516-35982014000400002

Copyright $(2014$ Sociedade Brasileira de Zootecnia. This is an Open Access article distributed under the terms of the Creative Commons Attribution Non-Commercial License, which permits unrestricted non-commercial use, distribution, and reproduction in any medium, provided the original work is properly cited. or stomacher and, less frequently, in silage juices produced by the use of a hydraulic press. No direct comparison of these methods could be found in the literature.

There is indication that differences in experimental methods may affect ethanol content in sugarcane silages and alcohol recovery, when analyzing the forage. Some experiments, in which plastic buckets with Bunsen valves were used as experimental silos and alcohol was analyzed in water extracts produced in a blender, have indicated ethanol content ranging from 50 to $80 \mathrm{~g} / \mathrm{kg} \mathrm{DM}$ in the silages (Pedroso et al., 2005; Souza et al., 2008). Higher ethanol levels (180 to $230 \mathrm{~g} / \mathrm{kg} \mathrm{DM}$ ) were obtained in trials in which silages were produced in PVC tube silos, with and without valves, and ethanol was analyzed in silage juices extracted by hydraulic press (Freitas et al., 2006; Pedroso et al., 2007).

Variations in fermentation of sugarcane silages can be expected as a result of natural variation in chemical composition and yeast population in the forage (Schmidt, 2008), but it is important to ensure that this variation is not a result of differences in experimental methods. The aim of this trial was to test the hypothesis that fermentation in sugarcane silages is not affected by the type of laboratory silo, but the recovery of ethanol and other fermentation products may be affected by the presence of valves and the method used to produce silage extracts. 


\section{Material and Methods}

Sugarcane (RB867515; 12 months old; second cut) was mechanically harvested with a Mentamit ${ }^{\mathbb{}}$ harvester, adjusted for a cut length between 5 and $10 \mathrm{~mm}$, and ensiled in three different types of laboratory silos (mini-silos): $9.7 \times 30 \mathrm{~cm}$ PVC tubes with tight lids fitted with rubber O-rings (seal rings), equipped or unequipped with Bunsen valves, and $20 \mathrm{~L}$ plastic buckets with tight lids and Bunsen valves. The amount of forage to be packed in each type of silo was calculated in advance aiming at a density of $600 \mathrm{~kg} / \mathrm{m}^{3}$ in the silage. The predetermined volume of forage was compressed into the PVC tubes using wood bars and into the buckets with the feet. Because of the use of "manual" filling, an extra amount of forage would occasionally have to be packed to avoid an empty space on the top of the silos. After filling, the lids of all silos were sealed with adhesive tape.

The mini-silos (five replicates) were weighed and the forage was sampled on days 0 and 139 days after ensiling. Gas losses were estimated by difference between the weight of the minisilos immediately after sealing and the weight at the end of the ensiling period (Weinberg et al., 2002; Siqueira et al., 2007), after removal of the adhesive tapes. Total DM loss (TDML) was calculated by DM weight loss in the silages. Samples for determination of ethanol, $\mathrm{pH}$, acetic and lactic acids were frozen $\left(-10^{\circ} \mathrm{C}\right)$ before analysis. Other samples were dried in a forced ventilation oven $\left(65^{\circ} \mathrm{C}, 48 \mathrm{~h}\right)$, ground in a Wiley mill through a $1 \mathrm{~mm}$ screen, and analyzed as follows: neutral detergent fiber (NDF) according to Van Soest and Robertson (1985); DM, ash and crude protein (CP), according to AOAC (1990).

Three methods were used to produce silage extracts to determine $\mathrm{pH}$, ethanol and acetic and lactic acids: extraction of silage juice by hydraulic press and production of water extracts using a stomacher or a blender. For extraction with the hydraulic press, $2 \mathrm{kgf} / \mathrm{cm}^{3}$ were applied to approximately $300 \mathrm{~g}$ of silage to produce $50 \mathrm{~mL}$ of juice, in which $\mathrm{pH}$ was immediately evaluated with a digital potentiometer. Juices were than centrifuged at 3,000 rpm for $15 \mathrm{~min}$ and $5 \mathrm{~mL}$ of supernatants were transferred to test tubes containing $1 \mathrm{~mL}$ of formic acid (PA). From these extracts, $1 \mathrm{~mL}$ was filtered through a Millex filter $(0.45 \mu \mathrm{m})$ and stored at $-10{ }^{\circ} \mathrm{C}$ until analysis. Water extracts were prepared by adding $25 \mathrm{~g}$ of silage to $225 \mathrm{~mL}$ of deionized water and homogenizing for $2 \mathrm{~min}$ at medium velocity in a stomacher (Logen LS-1901, Logen Scientific, SP, Br) or 2 min in a blender (Croydon - series 695, Croydonmaq Industrial Ltda, Duque de Caxias, RJ, Brazil). After pH measurement with a digital potentiometer, water extracts were filtered through a surgical gauze wad and processed in the same manner as the juices obtained with the hydraulic press. The extracts produced by the three methods were analyzed for ethanol and acetic acid, by gas chromatography according to Sigma-Aldrich, Co (1998), and lactic acid, using highperformance liquid chromatography (HPLC), according to Wilson (1971).

Data for DM, CP, NDF, ash, gas losses and TDML were analyzed as a complete randomized design, with three treatments (three types of mini-silos) and five replicates, and subjected to ANOVA by the GLM procedure of SAS (Statistical Analysis System, version 9.1). Differences among means were tested using LSMEANS procedure of SAS (Statistical Analysis System, version 9.1) and the $t$ test $(\mathrm{P}<0.05)$. Data for ethanol, acetic acid, lactic acid and $\mathrm{pH}$ were analyzed as a complete randomized design on a $3 \times 3$ factorial arrangement, with six treatments (three types of mini-silos and three methods of silage extract preparation) and five replicates, and subjected to ANOVA by the GLM procedure of SAS (Statistical Analysis System, version 9.1), considering the effects of silo, method of extract preparation and the silo $\times$ method of extract preparation interaction in the analysis. Differences among means were tested using LSMEANS procedure of SAS (Statistical Analysis System, version 9.1) and the $t$ test $(\mathrm{P}<0.05)$.

\section{Results and Discussion}

The chemical composition and losses of experimental silages (Table 1) were within values usually found in the literature for sugarcane silages produced without additives. The type of laboratory silo did not affect DM, CP, NDF or ash contents in the silages. Total DML was high in all silages (average $231 \mathrm{~g} / \mathrm{kg} \mathrm{DM}$ ), typical of sugarcane silages produced without yeast-controlling additives (Kung Jr. and Stanley, 1982), and was not affected by silo type. Despite

Table 1 - Chemical composition and losses of sugarcane silages produced in different types of laboratory silos ${ }^{1}$

\begin{tabular}{lcccc}
\hline & $\begin{array}{c}\text { PVC with } \\
\text { valve }\end{array}$ & $\begin{array}{c}\text { PVC without } \\
\text { valve }\end{array}$ & $\begin{array}{c}\text { Bucket with } \\
\text { valve }\end{array}$ & SE \\
\hline $\mathrm{DM}(\mathrm{g} / \mathrm{kg} \mathrm{FF})$ & 262 & 262 & 255 & 7.2 \\
Dens $\left(\mathrm{kg} / \mathrm{m}^{3}\right)$ & $601 \mathrm{~b}$ & $662 \mathrm{a}$ & $593 \mathrm{~b}$ & 43.7 \\
$\mathrm{CP}(\mathrm{g} / \mathrm{kg} \mathrm{DM})$ & 33.4 & 32.4 & 31.2 & 2.44 \\
$\mathrm{NDF}(\mathrm{g} / \mathrm{kg} \mathrm{DM})$ & 622 & 598 & 604 & 34.8 \\
Ash $(\mathrm{g} / \mathrm{kg} \mathrm{DM})$ & 29.6 & 29.2 & 28.2 & 1.80 \\
Gas losses $(\mathrm{g} / \mathrm{kg} \mathrm{DM})$ & $133 \mathrm{a}$ & $118 \mathrm{~b}$ & $124 \mathrm{ab}$ & 9.6 \\
TDML $(\mathrm{g} / \mathrm{kg} \mathrm{DM})$ & 225 & 223 & 244 & 22.8 \\
\hline
\end{tabular}

${ }^{1}$ PVC tubes $(9.7 \times 30 \mathrm{~cm})$ with Bunsen valves; PVC tubes $(9.7 \times 30 \mathrm{~cm})$ without Bunsen valves; plastic buckets $(20 \mathrm{~L})$ with Bunsen valves.

$\mathrm{a}, \mathrm{b}, \mathrm{c}, \mathrm{d}-$ Means within a row with different letters differ $(\mathrm{P}<0.05)$ by the $\mathrm{t}$ test

SE - standard error; DM - dry matter; FF - fresh forage; CP - crude protein; NDF neutral detergent fiber; TDML - total DM loss. 
the existing evidence that silage density affects DML during storage (Amaral et al., 2007), the small difference in density among silos observed in this experiment was not sufficient to affect TDML. Gas losses (average $125 \mathrm{~g} / \mathrm{kg}$ DM) corresponded to about $50 \%$ of TDML in the three types of silos, as previously observed by Pedroso et al. (2005) and Siqueira et al. (2010), and did not differ between PVC tubes with valves and plastic buckets with valves. The presence of gas losses in the PVC tubes without valves, equal to buckets with valves and smaller than in PVC tubes with valves, indicates that the rubber O-rings were not able to prevent gases from escaping after the adhesive tapes were removed, at the time the silos were weighed with lids on. This indicates the need for extra sealing even when lids provided with rubber O-rings are used in laboratory silos, if gases are not to be allowed to escape during storage.

The ethanol, acetic acid and lactic acid contents in silages (Table 2 and 3) were also within normal levels reported in the literature for sugarcane silages produced without additives (Freitas et al., 2006; Sousa et al., 2008). No interaction between silo type and method of silage extract production was observed for ethanol and organic acids contents in the silages; therefore, effects will be discussed separately for these parameters. Interaction between silo type and method of silage extract preparation was only detected for $\mathrm{pH}$ (Table 4).

The type of silo affected ethanol content but did not affect the concentration of lactic and acetic acids in the silages (Table 2). The silage produced in PVC tubes with valves had lower ethanol content compared with the silages produced in the two other types of silos, which had similar alcohol contents. Considering the similar composition in DM, CP, NDF, ash, lactic acid, acetic acid and TDML of silages produced in the three types of silos, it may be inferred that fermentation was not affected by silo type and, consequently, that ethanol production was the same in the different silos. Therefore, the variation in ethanol but not in lactic and acetic acid contents among silages

Table 2 - Fermentation parameters in sugarcane silages as affected by different types of laboratory silos ${ }^{1}$

\begin{tabular}{lccc}
\hline Silo type & Ethanol & Acetic acid & Lactic acid \\
\hline & & $(\mathrm{g} / \mathrm{kg} \mathrm{DM})$ \\
PVC with valve & $83.1 \mathrm{~B}$ & $38.2 \mathrm{~A}$ & $30.8 \mathrm{~A}$ \\
PVC without valve & $106.8 \mathrm{~A}$ & $34.2 \mathrm{~A}$ & $31.9 \mathrm{~A}$ \\
Bucket with valve & $116.3 \mathrm{~A}$ & $35.8 \mathrm{~A}$ & $33.2 \mathrm{~A}$ \\
Standard error & 16.5 & 6.5 & 5.5 \\
\hline
\end{tabular}

${ }^{1}$ PVC tubes $(9.7 \times 30 \mathrm{~cm})$ with Bunsen valves; PVC tubes $(9.7 \times 30 \mathrm{~cm})$ without Bunsen valves; plastic buckets $(20 \mathrm{~L})$ with Bunsen valves.

$\mathrm{A}, \mathrm{B}, \mathrm{C}-$ means within a column with different capital letters differ by the $\mathrm{t}$ test $(\mathrm{P}<0.05)$. might be explained by differences in the volatility of these components combined with differences in the ratio between the silage top surface area and the silage mass packed in the different silos (TSA:SM). Ethanol has a much higher vapor pressure than acetic acid (59.76 vs. $15.41 \mathrm{psi}$ ), indicating it is much more volatile, and lactic acid is not volatile. The PVC silos with valves had a higher TSA:SM compared with buckets with valves ( 0.17 vs. $\left.0.13 \mathrm{~cm}^{2} / \mathrm{g} \mathrm{DM}\right)$, which may have allowed more ethanol to escape through the valves in the PVC silos in relation to the amount of DM in the silos, reducing its concentration compared with the silage produced in buckets. As acetic acid is less volatile than ethanol, and lactic acid is not volatile, the TSA:SM of silos had no effect on the concentration of these acids. For the PVC tubes without valves, it may be inferred that although the escape of alcohol was avoided during storage by the adhesive tapes and rubber O-rings, the seal rings alone were not able to retain gases in the silos and a certain amount of volatilized ethanol escaped after the tapes were removed at the time the silos were weighed, causing the final ethanol concentration in these silages to be coincidently similar to the concentration in the silages produced in buckets with valves.

Table 3 - Fermentation parameters in sugarcane silages as affected by different methods of silage extract production ${ }^{1}$

\begin{tabular}{lccc}
\hline $\begin{array}{l}\text { Method of silage } \\
\text { extract production }\end{array}$ & Ethanol & Acetic acid & Lactic acid \\
\hline & & $(\mathrm{g} / \mathrm{kg} \mathrm{DM})$ \\
Blender & $127.7 \mathrm{~A}$ & $43.3 \mathrm{~A}$ & $33.0 \mathrm{~B}$ \\
Stomacher & $75.1 \mathrm{C}$ & $30.3 \mathrm{~B}$ & $18.9 \mathrm{C}$ \\
Hydraulic press & $103.5 \mathrm{~B}$ & $34.5 \mathrm{~B}$ & $44.0 \mathrm{~A}$ \\
Standard error & 16.5 & 6.5 & 5.5 \\
\hline 1 & PVC tubes $(9.7 \times 30 \mathrm{~cm})$ with Bunsen valves; PVC tubes $(9.7 \times 30 \mathrm{~cm})$ without \\
Bunsen valves; plastic buckets $(20 \mathrm{~L})$ with Bunsen valves. \\
A, B, C - means within a column with different capital letters differ by the t test \\
$(\mathrm{P}<0.05)$.
\end{tabular}

Table 4 - Sugarcane silage $\mathrm{pH}$ as affected by the type of laboratory silos $^{1}$ and different methods of silage extract production $^{2}$

\begin{tabular}{lcccc}
\hline & Blender & Stomacher & $\begin{array}{c}\text { Hydraulic } \\
\text { press }\end{array}$ & Mean $\pm \mathrm{SE}$ \\
\hline PVC with valve & $3.60 \mathrm{aA}$ & $3.65 \mathrm{aA}$ & $3.35 \mathrm{bA}$ & $3.54 \pm 0.01$ \\
PVC without valve & $3.57 \mathrm{aA}$ & $3.60 \mathrm{aA}$ & $3.35 \mathrm{bA}$ & $3.51 \pm 0.01$ \\
Bucket with valve & $3.53 \mathrm{aB}$ & $3.57 \mathrm{aB}$ & $3.37 \mathrm{bA}$ & $3.49 \pm 0.01$ \\
Mean \pm SE & $3.57 \pm 0.01$ & $3.61 \pm 0.01$ & $3.36 \pm 0.01$ & \\
\hline
\end{tabular}

${ }^{1}$ PVC tubes $(9.7 \times 30 \mathrm{~cm})$ with Bunsen valves; PVC tubes $(9.7 \times 30 \mathrm{~cm})$ without Bunsen valves; plastic buckets $(20 \mathrm{~L})$ with Bunsen valves.

${ }^{2}$ Extracts produced by means of a hydraulic press: $300 \mathrm{~g}$ of silage were used to produce $50 \mathrm{~mL}$ of juice; Water extracts prepared by adding $25 \mathrm{~g}$ of silage to $225 \mathrm{~mL}$ of deionized water and homogenizing for $2 \mathrm{~min} /$ medium velocity in a stomacher or $2 \mathrm{~min}$ in a blender.

$\mathrm{a}, \mathrm{b}, \mathrm{c}-\mathrm{means}$ within a row with different letters differ by the $\mathrm{t}$ test $(\mathrm{P}<0.05)$.

A, B, C - means within a column with different capital letters differ by the t test $(\mathrm{P}<0.05)$.

$\mathrm{SE}$ - standard error 
Previous research has indicated that the size and type of laboratory silos, as well as the amount of forage ensiled, have little effect on silage fermentation. Wilson and Wilkins (1972) compared silages made from 18 grasses and eight legumes, produced in PVC bags, test-tubes and polythene bag silos, containing respectively $1 \mathrm{t}, 100 \mathrm{~g}$ and $6 \mathrm{~kg}$ of forage, and concluded that the fermentation profile in the three types of silos agreed closely. Rodrigues et al (2002) did not detect differences in major fermentation parameters ( $\mathrm{pH}, \mathrm{N}-\mathrm{NH}_{3}$, volatile fatty acids, lactic acid) and DML when comparing corn silages produced in plastic buckets (12 L), plastic bags (40 L) and concrete pipes (630 L). Data presented here indicates that the presence of valves in the silos may affect recovery of ethanol, and possibly other volatile components produced during fermentation, in which case, silo structure or size may also influence recovery.

The method used to produce silage extracts affected the recovery of all fermentation products analyzed in the silages (Table 3). Recovery of ethanol and acetic acid was higher when silage extracts were produced using a blender, compared with recovery in extracts produced using a stomacher or a hydraulic press. For lactic acid recovery, the hydraulic press method was superior to the other two methods. In an overall view, the recovery of fermentation products was more effective when the blender method was used, intermediate when using a hydraulic press and lower when extracts were produced with a stomacher.

Stomachers were designed by Sharpe and Jackson (1972) to avoid "excessive labor needed to clean or sterilize homogenizer cups before reuse and other disadvantages of blenders normally used in laboratories, such as high noise level, temperature rises during sampling and high maintenance costs". In the stomacher technique, sample and diluent are put into a plastic bag which is vigorously pounded on its outer surfaces by paddles, when placed inside the equipment. In this experiment, it is possible that the intensity of "strokes" obtained, using the stomacher during two minutes at medium velocity was not enough to efficiently extract the fermentation products. The equipment guide did not present specifications and it was not possible to determine the number of strokes/min when the stomacher was set to medium velocity. Concerning the extraction of silage juice using a hydraulic press, one may speculate that the simple compression of the forage sample, without any stirring, allowed more cells to remain intact in relation to extraction by a blender, resulting in less effective recovery of the intracellular fraction of silage fermentation products under evaluation.

In some experiments in which silages were produced in plastic buckets $(20 \mathrm{~L})$ with Bunsen valves and alcohol was analyzed in water extracts produced in a blender, concentrations of ethanol in relatively low levels (50 to $80 \mathrm{~g} / \mathrm{kg} \mathrm{DM}$ ) were observed (Pedroso et al., 2005; Sousa et al., 2008). Higher concentrations of the alcohol (180 to $230 \mathrm{~g} / \mathrm{kg} \mathrm{DM}$ ) were obtained in some trials in which sugarcane silages were produced in PVC tubes, with and without Bunsen valves, and ethanol was analyzed in juices extracted by hydraulic press (Freitas et al., 2006; Pedroso et al., 2007). Considering these inter-experimental data, average alcohol concentration was three times greater when silages were produced in PVC tubes with valves and ethanol was analyzed in extracts produced with a hydraulic press, compared with silages produced in buckets with valves and extracts produced using a blender. Inversely, in the present trial, the ethanol concentration obtained in the PVC tubes with valves/hydraulic press treatment was approximately two times lower than that obtained in the buckets with valves/blender treatment ( 77.5 vs. $139.0 \mathrm{~g} / \mathrm{kg}$ $\mathrm{DM})$. These results indicate that the great variation in ethanol content frequently observed among experiments involving the ensilage of sugarcane is not caused only by differences in the type of microsilo or the method used to produce silage extracts. It may be concluded that interexperimental differences in major fermentation products in sugarcane silages are probably also resultant from natural differences in fermentation caused by variations in the epiphytic microflora and intrinsic characteristics of the sugarcane used in the experiments, as postulated by Schmidt (2008).

All silages presented adequate $\mathrm{pH}$ (Table 4) but values were lower when $\mathrm{pH}$ was analyzed in juices produced with the hydraulic press, for the three types of silos. The more efficient extraction of lactic acid may have led to a lower $\mathrm{pH}$ in these extracts produced (Table 3), compared with the other two methods. Among silos, $\mathrm{pH}$ was lower for silage produced in buckets compared with the two other types of silo, when analysis was performed in extracts produced with a blender or a stomacher. This result cannot be explained since there was no difference in the concentration of acids among silos (Table 2). Analysis in juices produced with the hydraulic press did not detect differences in $\mathrm{pH}$ among silages produced in the three types of silos.

Traditional crop silages with intense alcoholic fermentation tend to show inadequate final $\mathrm{pH}$ (Driehuis and Wikselaar, 2000) but the low buffering capacity of sugarcane allows rapid $\mathrm{pH}$ drop even if relatively small amounts of acids are produced during ensilage (Alli et al., 1983). Despite the high levels of ethanol, these silages normally present final $\mathrm{pH}$ around 3.5 (Pedroso et al., 2005). 
Yeasts are not inhibited though by $\mathrm{pH}$ levels normally found in silages (McDonald et al., 1991) and lactic acid has a weak direct fungicidal activity (Moon, 1983). Accordingly, the low $\mathrm{pH}$ and the lactic acid present in the silages were unable to restrict yeast development also in this experiment, evidenced by high ethanol contents and high gaseous and total DM losses observed in the silages (approx. $231 \mathrm{~g} / \mathrm{kg}$ DM, on average). In this case, high DM loss was expected, considering that fermentation of sugars by yeasts results in approximately $49 \%$ loss of substratum as $\mathrm{CO}_{2}$ and $\mathrm{H}_{2} \mathrm{O}$ (McDonald et al., 1991).

Alcoholic fermentation is the greatest restriction when ensiling sugarcane. It is well known that uncontrolled yeast development results in intense consumption of sugars (up to $700 \mathrm{~g} / \mathrm{kg}$ ) in the ensiled forage and dry matter losses ranging from 200 to $300 \mathrm{~g} / \mathrm{kg}$ have been reported since early evaluations of these silages (Alli et al., 1982; Pedroso et al., 2005). Therefore, the use of yeast-controlling additives is considered essential in the ensilage of sugarcane and can greatly improve DM recovery and the quality of these silages (Siqueira et al., 2007). Most additives are expected to inhibit alcoholic fermentation by increment in the concentration of yeast-controlling acids, such as propionic and acetic acids, in the silages. Salts of propionic acid are used to increase propionic acid content and inoculants containing heterolactic bacteria are expected to enhance acetic acid concentration in the inoculated silages (Siqueira et al., 2010). Consequently, the proper determination of ethanol and organic acids contents in sugarcane silages is essential when evaluating the effectiveness of additives and becomes even more important when comparing results from different trials. The results presented here confirmed the hypothesis that fermentation is not affected by type of laboratory silo. The recovery of fermentation products was shown to be affected by both the type of silo combined with the presence of gas valves and the method used to produce silage extracts.

\section{Conclusions}

Variations in experimental methods influence the recovery of fermentation products in sugarcane silages. Therefore, caution must be taken when comparing interexperimental results and efforts should be made aiming at the standardization of experimental procedures.

\section{Acknowledgments}

To FAPESP (São Paulo Research Foundation) for supporting the project - grant 2009/05362-2.

\section{References}

Alli, I.; Baker, B.E. and Garcia, G. 1982. Studies on the fermentation of chopped sugarcane. Animal Feed Science and Technology 7:411-417.

Alli, I.; Fairbairn, R.; Baker, B. E. and Garcia, G. 1983. The effects of ammonia on the fermentation of chopped sugarcane. Animal Feed Science and Technology 9:291-299.

Amaral, R. C.; Bernardes, T. F.; Siqueira, G. R. and Reis, R. A. 2007. Características fermentativas e químicas de silagens de capimmarandu produzidas com quatro pressões de compactação. Revista Brasileira de Zootecnia 36:532-539.

AOAC - Association of Official Analytical Chemistis. 1990. Official methods of analysis. 15th ed. v.1. Arlington, VA, USA.

Cherney, D. J. R.; Cherney, J. H. and Cox, W. J. 2004. Fermentation characteristics of corn forage ensiled in mini-silos. Journal of Dairy Science 87:4238-4246.

Driehuis, F. and Wikselaar, P. G. 2000. The occurrence and prevention of ethanol fermentation in high-dry-matter grass silage. Journal of Science of Food and Agriculture 80:711-718.

Freitas, A. W. P.; Pereira, J. C.; Rocha, F. C.; Costa, M. G.; Leonel, F. P. and Ribeiro, M. D. 2006. Avaliação da qualidade nutricional da silagem de cana-de-açúcar com aditivos microbianos e enriquecida com resíduo da colheita de soja. Revista Brasileira de Zootecnia 35:38-47.

Kung Jr., L. and Stanley, R. W. 1982. Effect of stage of maturity on the nutritive value of whole-plant sugarcane preserved as silage. Journal of Animal Science 54:689-696.

McDonald, P.; Henderson, A. R. and Heron, S. J. E. 1991. The biochemistry of silage. 2nd ed. Chalcomb Publ., Marlow.

Moon, N. J. 1983. Inhibition of the growth of acid tolerant yeasts by acetate, lactate and propionate and their synergistic mixtures. Journal of Applied Bacteriology 55:453-460.

Pedroso, A. F.; Nussio, L. G.; Paziani, S. F.; Loures, D. R. S.; Igarasi, M. S.; Coelho, R. M.; Packer, I. H.; Horii, J. and Gomes, L. H. 2005. Fermentation and epiphytic microflora dynamics in sugar cane silage. Scientia Agricola 62:427-432.

Pedroso, A. F.; Nussio, L. G.; Loures, D. R. S.; Paziani, S. F.; Igarasi, M. S.; Coelho, R. M.; Horii, J. and Rodrigues, A. A. 2007. Efeito do tratamento com aditivos químicos e inoculantes bacterianos nas perdas e na qualidade de silagens de cana-de-açúcar. Revista Brasileira de Zootecnia 36:558-564.

Rodrigues, P. H. M.; Pedroso, S. B. G.; Melotti, L.; Andrade, S. J. T. and Lima, F. R. 2002. Estudo comparativo de diferentes tipos de silos sobre a composição bromatológica e perfil fermentativo da silagem de milho. Acta Scientiarum 24:1127-1132.

Schmidt, P. 2008. Aditivos químicos e biológicos no tratamento da cana-de-açúcar para alimentação de bovinos. p.117-152. In: Produção e utilização de forragens conservadas. Jobim, C. C.; Cecato, U. and Canto, M. W., eds. UEM, Maringá.

Sharpe, A. N. and Jackson, A. K. 1972. Stomaching: a new concept in bacteriological sample preparation. Applied Microbiology 24:175-178.

Sigma-Aldrich Co. 1998. Analyzing fatty acids by packed column gas chromatography. Bulletin 856B. Supelco, Bellefonte, PA, USA.

Siqueira, G. R.; Reis, R. A.; Schocken-Iturrino, R. P.; Pires, A. J. V. and Bernardes, T. F. 2007. Perdas de silagens de cana-de-açúcar tratadas com aditivos químicos e bacterianos. Revista Brasileira de Zootecnia 36:2000-2009.

Siqueira, G. R.; Reis, R. A.; Schocken-Iturrino, R. P.; Pires, A. J. V.; Bernardes, T. F. and Roth, M. T. P. 2010. Queima e aditivos químicos e bacterianos na ensilagem de cana-de-açúcar. Revista Brasileira de Zootecnia 39:103-112. 
Sousa, D. P.; Mattos, W. R. S.; Nussio, L. G.; Mari, L. J.; Ribeiro, J. L. and Santos, M. C. 2008. Efeito de aditivo químico e inoculantes microbianos na fermentação e no controle da produção de álcool em silagens de cana-de-açúcar. Revista Brasileira de Zootecnia 37:1564-1572.

Van Soest, P. J. and Robertson, J. B. 1985. Analysis of forages and fibrous foods. Cornell University, Ithaca.

Weinberg, Z. G.; Ashbell, G.; Hen, Y.; Azrieli, A; Szakacs, G. and Filya, I. 2002. Ensiling whole-crop wheat and corn in large containers with
Lactobacillus plantarum and Lactobacillus buchneri. Journal of Industrial Microbiology \& Biotechnology 28:7-11.

Wilson, R. K. A. 1971. A rapid accurate method for measuring volatile fatty acids and lactic acid in silage. Research Report. Agricultural Institute, Dunsinea Research Centre, Dublin, Ireland.

Wilson, R. F. and Wilkins, R. J. 1972. An evaluation of laboratory ensiling techniques. Journal of the Science of Food and Agriculture 23:377-382. 